\title{
Implementation of Online Learning Using Online Media, During the Covid 19 Pandemic
}

\author{
Nanda Saputra ${ }^{1}$, Nurul Hikmah ${ }^{2}$, Via Yustitia ${ }^{3}$, Miswar Saputra $^{4}$, Abdul Wahab $^{5}$, \\ Junaedi $^{6}$ \\ ${ }^{1}$ University of STIT Al-Hilal Sigli, Indonesia \\ ${ }^{2}$ University of UWGM Samarinda, Indonesia \\ ${ }^{3}$ University of PGRI Adi Buana Surabaya, Indonesia \\ ${ }^{4}$ Institut Agama Islam Al Aziziyah Samalanga Aceh Indonesia \\ ${ }^{5}$ Universitas Muslim Indonesia \\ ${ }^{6}$ Institut Agama Islam Darud Da'wah Wal-Irsyad Polewali Mandar, Indonesia \\ nandasaputra680@gmail.com,nurul@uwgm.ac.id,via.yustitia@unipasby.ac.id,miswaralfata@gmail.com, \\ abdulwahab79@umi.ac.id,junaedi@ddipolman.ac.id
}

\begin{abstract}
Due to outbreak of the Covid 19, the implementation of education and learning has extremely changed. Face to face meetings as a conventional learning is no longer conducted, in contrast, online learning is more often employed. Thus, a solution to this problem is required to respond to this problem. Online learning is an alternative that can overcome this problem. The purpose of this research is to get a reflection of the implementation of online education by using online media to reduce the outbreak of Covid19 in universities. The research subjects were PGMI students who were interviewed through Zoom Cloud Meeting to collect the data. The data analysis employed was an interactive analysis method Miles \& Huberman. The results of the research showed that: (1) the students had already had the basic facilities needed to explore online education; (2) the online education was flexibly being implemented, encouraging learning independently, motivating to learn more actively; and (3) long distance education urges the students to get used to social distancing attitude and minimizes crowds to reduce the outbreak of Covid-19 in institutions tertiary. The lack of supervision of students, lack of internet signals in remote areas, and high quota payments were challenges in online education. The increasing of independent learning, attention, motivation, and the courage to express ideas and problems was another advantage of online education.
\end{abstract}

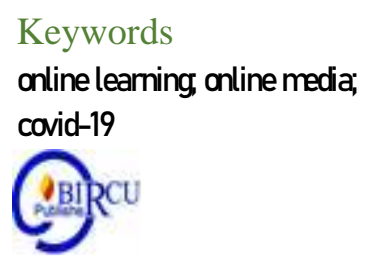

Keywords online learning, online media; covid-19

\section{Introduction}

In instructional design, learning is a programmed activity intended to make the lesson active (Sagala, 2011: 62), thus, an interaction occurs between students and teachers. Furthermore, students are unable to carry out learning without a teacher, therefore, the two parties are closely related. Law No. 20 of 2003 with regard to the national education system, article 1 verse 20 states learning is an interaction between students, educators, and lesson resources in a learning environment.

However, the learning process was impeded in March 2020. This was due to the covid-19 pandemic, where, schools were consequently unable to carry out direct/face-toface learning, and resorted to an online process (daring), from the Kindergarten to University level. 
Thus, the online learning is an effort to support the government in preventing Covid19 spread within educational settings. Daring is an acronym for "dalam jaringan", a substitute for the word "online", often used in relation to internet technology, where applications or social networks are used. Wahid (2020) stated that Covid-19 has bridged the rapidly increasing use of social media / internet, the existence of a distance learning system (online) proving that this pandemic has focused on learning shifting from conventional to distance or online (in the network).

Therefore, any suitable lectures serving as a solution during the Covid-19 pandemic was regarded as online education. According to Dickson-Deane et al., (2011), online learning is conducted using an internet network with accessibility, connectivity, flexibility, and expertise, to create various types of educational interactions. A study by Zhang (2004) showed the use of internet and multimedia technology is able to revolutionize the method of conveying knowledge and is also a possible alternative to conducting learning in traditional classrooms. Thus, this is able to bring students and lecturers together, to interact with education, using internet support (Kuntarto, 2017).

At the implementation level, online learning requires mobile devices support, for instance, smartphones or Android phones, laptops, PCs, tablets, or iPhones, in order to access data at any time or place (Gikas and Grant, 2013). Therefore, during the work-fromhome period, Universities need to strengthen online education (Darmalaksana, 2020). Online learning has been a demand in the learning field over the last few years $(\mathrm{He}, \mathrm{Xu}$, and Kruck, 2014), and is also required in education, as part of the 4.0 industrial revolution (Nugroho et al., 2019).

In the online learning scenarios according to Khan (2009) where the building of an online curriculum is mostly instinctive. Moreover, students have more elasticity in deciding when, how, and with what content and actions they engage (Milligan \& Littlejohn, 2014). This flexibility requires students to monitor and adjust their behavior and actions concerning the specific learning context (Zimmerman, 2000) (Reotutar, 2020).

The use of mobile technology has a major contribution in learning institutions, and this is the achievement of distance education goals (Korucu and Alkan, 2011). Several media are also suitable for supporting online education implementation, for instance, virtual classes use Google Classroom, Edmodo, and Schoology services (Enriquez, 2014; Sicat, 2015; Iftakhar, 2016), as well as practical messaging applications, including WhatsApp (So, 2016). This is especially possible through social media, including Facebook and Instagram (Kumar and Nanda, 2018). Furthermore, online learning connects students with physically separated or far apart learning resources, and provides an opportunity to talk, connect or collaborate (synchronously and asynchronously). Prasasti (2019) stated that the use of technology media provides benefits for teachers and students to access learning materials and interact directly in learning in the classroom, and also outside the classroom through online media. Thus, online education is also a form of distance education using telecommunication technology and data, for instance, using the internet, and CD-ROM (Molinda, 2005).

The use of online media is therefore an approach to enable students master lesson modules properly. This is in line with the report by Ibrahim and Suardiman (2014), stating the use of e-learning has a positive effect on student motivation and learning achievement, at the Yogyakarta Tahunan State Elementary School. Online education was also implemented at the Tarbiyah Science College of Al-Hilal Sigli, during the work from home implementation, on March 18, 2020, within the covid-19 pandemic period. The online media used include youtube, whatsapp groups, google classroom, and quizzes, while modules were provided in the form of powerpoints, short videos, and text materials. 
However, in this implementation, an assessment is required to obtain a clear revision, based on information. This prompts the author to understand the effectiveness of online education using online media, in Indonesian language courses.

\section{Research Methods}

This study used a qualitative method to describe the online education conducted in the Madrasah Ibtidaiyah Teacher Education (PGMI) Study Program, in the Tarbiyah Science College (STIT) of Al-Hilal Sigli, as an effort to suppress Covid-19 spread within the university environment. In this study, online education is as conducting learning and teaching activities with online media.

The study began with a survey on students using online education, distributed with a google form, through WhatsApp messages, and 86 subjects shared reactions to the distributed survey. Subsequently, the survey results were grouped into 3 types of student reactions. These were, agree with the online education implementation, do not agree with the online education implementation, and doubtful about the online education implementation.

The research subjects were students of the Madrasah Ibtidaiyah Teacher Education Study Program at the Tarbiyah Science College of Al-Hilal Sigli, undergoing online education. The 12 subjects were grouped based on reactions into 4 students in class 2017, 4 in class 2018, and 4 in class 2019, as well as 8 males and 4 females.

Meanwhile, information was collected through telephone interviews and/or zoom cloud meetings. The interview aspects were, the student's facilities and infrastructure to carry out online education, responses regarding the effectiveness of online learning, implementation of online education in breaking the chain of Covid-19 spread within university institutions. Subsequently, analysis of research information was performed with the Miles and Huberman analysis model (1994) consisting of 3 stages, information reduction, display, as well as conclusion drawing and verification.

\section{Results and Discussion}

\subsection{Students Have Sufficient Facilities For Conducting Online Education}

The increase in internet usage increase within Indonesia was influenced by the growth of data and communication technology (Rahadian, 2017). In 2018, 62.41\% of Indonesians already had cell phones and $20.05 \%$ of households had a PC (Badan Pusat Statistik, 2019). This information is relevant to the research results, stating some students do not own a laptop, while most already own a smartphone. According to the survey, 54 people own smartphones and laptops, while 42 people only own smartphones.

In addition, the use of smartphones and laptops in online education helps to improve student participant learning outcomes (Anggrawan, 2019). Nugroho et al., (2019) reported numerous advantages to using data and communication technology in the online education implementation, including the absence of space and time limitations. Numerous researchers have also studied the use of devices including smartphones and laptops, in education. The expertise of smartphones and laptops in accessing the internet helps students explore online education (Kay and Lauricella, 2011; Gikas and Grant, 2013; Chan et al., 2015; Gokfearslan et al., 2016). Online education through zoom cloud meetings also has the advantage of providing direct contact between students, lecturers and teaching materials, but is limited by wasteful quotas and inefficiency, in cases where there are over 20 students. (Naserly and Meter, K., 2020). 
The main challenge for online education is internet services availability. Several students access the internet using cellular services, while a small proportion use WiFi services. After the online education policy was implemented at STIT Al-Hilal Sigli, students returned home, and many experienced limited cellular signal. This is a particular challenge in implementing online education at STIT Al-Hilal Sigli. Thus the weakness of online education is limited internet services and poorly understood lecturer instructions on the part of students (Astuti and Febrian, 2019).

Another challenge faced is the high cost of online education. The students disclosed the high cost of internet quota required to explore online education. For these students, education in the form of video conferencing consumes a lot of internet quotas and is quite expensive (Naserly and Meter. K, 2020), while online dialogue through messaging applications, requires less. On average, students spend Rp. 100,000 to Rp. 200,000 per week, depending on the cellular provider.

Thus, the use of gadgets is able to support online education, however, there are negative impacts in terms of distractions, presumably due to excessive gadget usage. This is because students also use gadgets for social media as well as YouTube, not just for education. According to Lau (2017), social media has penetrated the realm of early age group life, and students access social media for self-expression, and to build networks of friends as well as opinions (Kim and Wang, 2016). Unfortunately, numerous people are addicted to devices, due to excessive usage (Waslh et al., 2007). Thus, there is a need to worry about the inclusion of misleading data and inattention during learning, due to distraction from social media (Siddiqui and Singh, 2016). Furthermore, students addicted to devices or gadget tend to have academic and social (Kwon, 2013), as well as emotional and attitudinal problems. (Asif, and Rahmadi, 2017).

\subsection{Online Learning Implementation}

The online education conducted by the PGMI Study Program of STIT Al-Hilal Sigli to break the Covid-19 spread using educational applications, is accessible through the internet network. Relatively, students are satisfied with flexible education, as there are no time constrains, and lectures can be attended from home, or anywhere else. Thus, through online education, the lectures in virtual classes are accessible from any place or time. This allows students to freely follow courses and determine prioritized assignments. A report by Sun (2008) research showed time flexibility, education procedures, and location of online education affect student satisfaction with education.

In addition, there was a unique finding, where students felt safer in expressing ideas and problems during online learning. This helps students avoid the psychological peer pressure usually experienced during face-to-face education. The indirect attendance of lecturers also makes students feel comfortable expressing ideas. Also, the absence of physical space and time barriers makes students feel safer while speaking (Sun, 2008), and online education eliminates clumsiness, making freely expressing questions and ideas possible.

Online education also has the advantage of being able to increase learning independence, due to the use of online applications (Oknisih and Suyoto, 2019). A study by Kuo (2014) reported online education to be more student-centered, thus, responsibility creation and autonomy in learning (learning autonomy) is possible. In addition, online learning requires students to self-prepare, and simultaneously evaluate, control, as well as maintain motivation in learning (Sun, 2014; Aina and Meter, 2016), while increasing student attention (Sobron and Bayu, 2019). 
However, online education has special challenges. The physical distance between students and lecturers makes direct supervision of student activities impossible throughout the education process, and there is no guarantee students are serious in observing the lecturers' discussion. Moulton et al., (2013) stated students fantasize more often in online lectures, compared to face-to-face. Therefore, online education is recommended for only a short time, considering the difficulty students experience in concentrating, during online lectures held for over an hour (Khan, 2012).

The results also showed a few students had difficulty in mastering the online lecture modules. Teaching materials are often shared in the form of text and are not easily understood by all students (Sadikin and Hakim, 2019). The modules and assignments were assumed to be suitable because direct explanations from the lecturers were required. According to Cleveland Innes (2005) and Swan (2002), classes where lecturers attend to share explanations of education material are better, compared to classes where explanations aren't often shared.

\subsection{Online Education Breaks the Chain of Covid-19 Spread in University}

The Covid-19 outbreak has a very large and comprehensive level of spread. This disease affects the human immune and respiratory systems (Rothan and Byrareddy, 2020), and is prevented by avoiding direct interaction between infected people as well as people dangerously exposed to the virus (Caley, Philp and McCracken, 2008). Also, controlling distance and physical contact with the opportunity to spread the virus is called social distancing (Bell, 2006).

STIT Al-Hilal Sigli practices online education in an effort to suppress the chain of Covid-19 spread in the campus area. Both parties use the internet to interact online, and lecturers ensure teaching materials are accessible at any time and place.

According to Bell (2017), online education allows interaction through websites, whether in remote or different places (Arzayeva, 2015). The different location of students in implementing education eliminates physical contact and encourages social distancing. Stein (2020) also regards implementing social distancing as a good effort to avoid Covid19 spread.

The implementation of online education allows both parties to conduct lectures from respective homes. Students are able to access lecture modules and send assignments without having to meet physically on campus. This reduces crowd on campus, for instance, in face-to-face lectures. The World Health Organization (2020) also recommends social distancing for preventing Covid-19 transmission.

Unfortunately, the application of online education shows a different trend in remote areas without good internet access. Thus, students living in areas with weak internet signals ought to go to certain areas, for instance, hills and areas near sub-districts office, to get internet access. 


\section{Conclusion}

In order to break the chain of Covid-19 spread in the campus area, the Madrasah Ibtidaiyah Teacher Education (PGMI) Study Program of STIT Al-Hilal Sigli conducts online education as a solution to physical learning during the Covid-19 pandemic. Based on the results, students have the facilities and infrastructure for conducting online education, and this is efficient to tackle problems in education, allowing lecturers and students to connect in virtual classes, at any time or place. Furthermore, online education increases motivation and ensures students learn independently. However, there are several weaknesses in online education, including the inability to monitor students properly throughout the process. Also, weak internet signals and high quota payments present certain challenges for online education. Despite this, online education reduces the spread of Covid-19 in universities.

\section{References}

Darmalaksana, 2020. Whats App Kuliah Mobile. Fakultas Ushuluddin UIN Sunan Gunung Djati Bandung.

Enriquez. 2014. Students Perceptions on the Effectiveness of the Use of Edmodo as a Supplementary Tool for Learning. DLSU Research Congress 2014. https://xsite.dlsu.edu.ph/conferences/dlsu_research_congress/2014/_pdf/proceedings/ LLI-II-010-FT.pdf, diakses tanggal 15 Oktober 2020.

Gikas, J., \& Grant, M. M. 2013. Mobile computing devices in higher education: Student perspectives on learning with cellphones, smartphones \& social media. Internet and Higher Education. https://www.sciencedirect.com/science/article/abs/pii/S10967516 13000262, diakses tanggal 15 Oktober 2020.

He, W., Xu, G., \& Kruck, S. 2014. Online IS Education for the 21st Century. Journal of Information Systems Education. https://www.questia.com/library/journal/1G1406164669/online-is-education-for-the-21st-century, diakses tanggal 15 Oktober 2020.

Ibrahim, D. S., \& Suardiman, S. P. 2014. Pengaruh Penggunaan E-Learning Terhadap Motivasi Dan Prestasi Belajar Matematika Siswa Sd Negeri Tahunan Yogyakarta. Jurnal Prima Edukasia, 2 (1), 66. diakses tanggal 15 Oktober 2020.

Korucu, A. T., \& Alkan, A. 2011. Differences between m-learning (mobile learning) and elearning, basic terminology and usage of m-learning in education. Procedia - Social and Behavioral Sciences. https://files.eric.ed.gov/fulltext/ED593111.pdf, diakses tanggal 15 Oktober 2020.

Kumar, V., \& Nanda, P. 2018. Social Media as a Tool in Higher Education: A Pedagogical Perspective. International Journal of Information and Communication Technology Education. https://www.igi-global.com/gateway/chapter/234258, diakses tanggal 15 Oktober 2020.

Kuntarto, E. 2017. Keefektifan Model Pembelajaran Daring dalam Perkuliahan Bahasa Indonesia di Perguruan Tinggi. Indonesian Language Education and Literature, 3 (1), https://syekhnurjati.ac.id/jurnal/index.php/jeill/article/view/1820, diakses tanggal 15 Oktober 2020.

Molenda, Michael. 2005. Instructional Technology and Media for Learning. New Jersey Colombus, Ohio.

Moore, J. L., Dickson-Deane, C., \& Galyen, K. 2011. E-Learning, online learning, and distance learning environments: Are they the same? Internet and Higher Education. 
https://www.sciencedirect.com/science/article/abs/pii/S1096751610000886, diakses tanggal 15 Oktober 2020.

Pangondian, Santosa, \& Nugroho. 2019. Faktor-Faktor Yang Mempengaruhi Kesuksesan Pembelajaran Daring Dalam Revolusi Industri 4.0. Seminar Nasional Teknologi Komputer \& Sains, Vol. 1, No. 1, file:///c:/users/lenovo/downloads/122-122-1pb\%20(1).pdf, diakses tanggal 15 Oktober 2020.

Prasasti, T.I., et al. (2019). The Effectiveness of Learning Media Folklore Text of North Sumatera Based on Blended Learning by 10th Grade Students of Vocational High SchoolHarapan Mekar-1 Medan. Budapest International Research and Critics in Linguistics and Education (BirLE) Journal. P. 480-490.

Reotutar, M.A.C. (2020). Teacher Education Freshmen Applicants' Current State in the New Normal's Learning Delivery Platforms. Budapest International Research and Critics in Linguistics and Education (BirLE) Journal. P. 1528-1536.

So, Simon. 2016. Mobile Instant Messaging Support For Teaching And Learning In Higher Education. Internet and Higher Education. https://www.sciencedirect.com/science /article/abs/pii/S1096751616300343, diakses tanggal 15 Oktober 2020.

Wahid, R., et al. (2020). Digital Activism: Covid-19 Effects in Campus Learning. Budapest International Research and Critics in Linguistics and Education (BirLE) Journal. P. 1336-1342.

Zhang, D., Zhao, J. L., Zhou, L., \& Nunamaker, J. F. 2004. Can E-Learning Replace Classroom Learning? Communications of the ACM. https://arizona.pure.elsevier .com/en/publications/can-e-learning-replace-classroom-learning, diakses tanggal 15 Oktober 2020.

Zimmerman, B. J. (2000). Attaining self-regulation: A social-cognitive perspective. In M. Boekaerts, P. R. Pintrich, \& M. Zeidner (Eds.), Handbook of self-regulation, (pp. 1339). San Diego: Academic. 